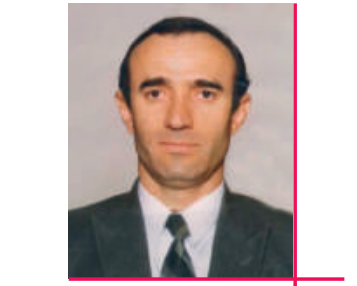

Казимагомедов И. Е.
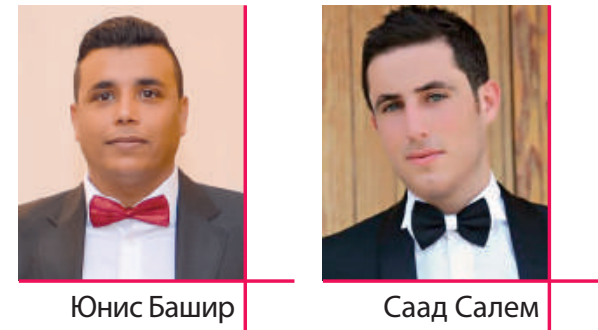

Казимагомедов И. Е., к.т.Н.,

доцент кафедры строительных материалов и изделий,

๘+38 (097) 992-46-03凶 kazimagomedov.1957@mail.ru,

Юнис Башир, к.Т.н.

доцент кафедры строительной механики,

๘+38 (093) 661-04-94凶 docbasheer01@gmail.com,

Саад Салем, аспирант,

๘+38 (093) 528-06-35凶 sesonoor@yahoo.com

Харьковский национальный университет

строительства и архитектуры (ХНУСА),

ул. Сумская, 40, г. Харьков, 61002
Ibrahim Kazimagomedov, Ph.D.,

assistant professor of building materials and products Department

๙ +38 (097) 992-46-03凶kazimagomedov.1957@mail.ru,

Basheer N. Younis, Ph. D.,

assistant professor of structural mechanics Department

๘+38 (093) 661-04-94凶 docbasheer01@gmail.com,

Saad Salem, postgraduate student,

๘+38 (093) 528-06-35凶 sesonoor@yahoo.com

Kharkiv National University

of Civil engineerng and Architecture,

Str. Sumy, 40, Kharkov, 61002

\title{
ФИЛЬТРЫ ДЛЯ КОЛОДЦЕВ ИЗ КРУПНОПОРИСТОГО БЕТОНА НА ЗАПОЛНИТЕЛЕ МЕЛКОЙ ФРАКЦИИ
}

\section{ФІЛЬТРИ ДЛЯ КОЛОДЦЕВ 3 КРУПНОПОРИСТОГО БЕТОНУ НА ЗАПОВНЮВАЧІ ДРІБНОї ФРАКЦІї FILTERS FOR WELLS MADE OF MACRO POROUS CONCRETE ON THE PLACEHOLDER, SMALL FRACTION}

Аннотация. В статье рассматриваются способы оптимизации состава и способов формования трубчатых колодцев, повышения их продуктивности и продления срока эксплуатации. Результаты проведенных исследований позволяют организовать работы по выпуску фильтрованных колец из крупнопористого бетона для колодцев с повышенной фильтрацией.

Ключевые слова: фильтры, скважины, пористый бетон, макропористый бетон, заполнитель.

Анотація. У статті розглядаються способи оптимізації складу і способів формування трубчастих колодязів, підвищення їх продуктивності і продовження терміну експлуатації. Результати проведених досліджень дозволяють організувати роботи по випуску фільтрованих кілець із крупнопористого бетону для колодязів з підвищеною фільтрацією.

Ключові слова: фільтри, свердловини, пористый бетон, макропористий бетон, заповнювач.

Summary. This article discusses how to optimize the composition and methods of forming tube wells, to increase productivity and extend the life. Research results can organize work to produce filtered macroporous concrete rings for wells with high filtration.

Keywords: ters, wells, porous concrete, macroporous concrete, aggregate.

Подземные, или грунтовые, воды образуются преимущественно в результате проникновения в землю атмосферных осадков и воды из открытых водоемов - рек, озер, прудов. Называются эти воды инфильтрационными, или вадозными. Различные породы в земной коре залегают пластами. Если порода пласта способна отдавать воду при вскрытии ее шахтой, она называется водоносной; порода, не пропускающая воду и не отдающая ее, называется водоупорной, или водонепроницаемой. Наличия в каждой породе пор и пустот, свидетельствует проницаемости пород, и чем этих пор и пустот больше, тем водопроницаемость породы выше. Так, галечники, гравий, крупные и средние пески, трещиноватые скальные породы имеют хорошую водопроницаемость. Напротив, глины, не выветрившиеся скальные породы водоупорны. Суглинки, лёсс, глинистые пески, мергели относятся к полупроницаемым породам.

Каждый вышележащий пласт породы, независимо от его водопроницаемости, является кровлей для пласта нижележащего. По гидравлическим свойствам подземные воды могут быть безнапорными (грунтовыми) и напорными (артезианскими).

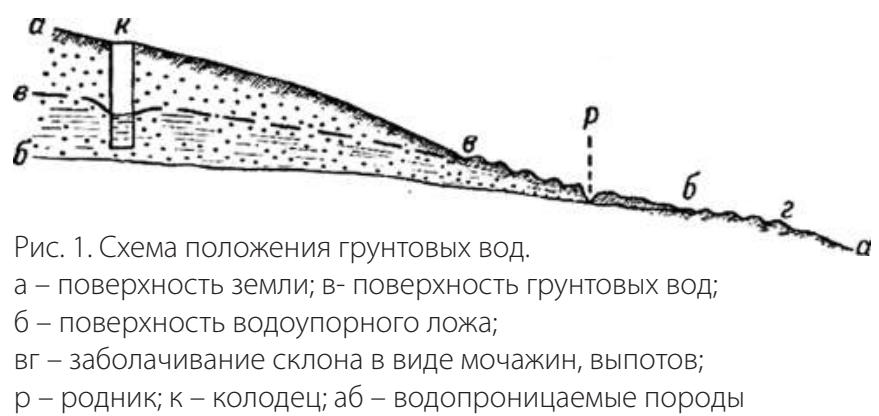

Безнапорные воды залегают на первом от поверхности земли водонепроницаемом или слабопроницаемом слое. Поверхность их свободная, то есть давление на ней равно атмосферному. В этом случае в скважинах и колодцах, вскрывающих воду, ее уровень обычно устанавливается на глубине, соответствующей уровню воды в водоносном пласте.

В маломощных водоносных слоях иногда устраивают приток воды через боковые отверстия, сверленные в кольцах, которые выполняются горизонтальными (рис. 2). С внешней стороны засыпают гравием, чтобы предохранить колодец от заноса песком. Однако лучше выполняют эту функцию специальные фильтры, которые устанавливают на растворе в боковые стенки или же формуют такие фильтры непосредственно при изготовлении колец. Наибольшее распространение получили фильтры из крупнопористого бетона, то есть бетона без мелкого заполнителя (песка).

Размеры зерен гравия и щебня для крупнопористого бетона подбирают в зависимости от крупности зерен песка водоносного слоя в соотношении 1: 5-10. (рис. 3). Крупный заполнитель обволакивают сметанообразной смесью цемента с водой, укладывают в форму и слегка вибрируют.

Использование стеновых колец из крупнопористого бетона для фильтрации является одним из наиболее эффективных способов сооружения колодезной шахты. Диаметр бетонных колец может быть от 0,75 до 2 метров, с градацией через 25 мм. Стандартная высота бетонных колодезных колец составляет 0,8-0,9 м. Для устройства колодезной шахты правильнее использовать кольца с замком, что позволит добиться герметичности ствола колодца из бетона. Если использовать бетонные кольца без замков, то железобетон- 


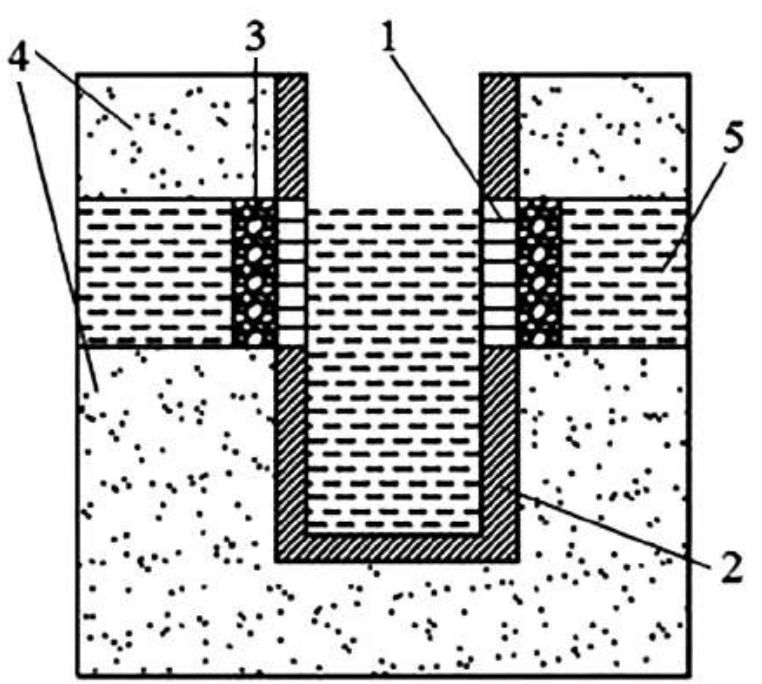

Рис. 2. Приток воды

через боковые отверстия в кольцах колодца

1 - боковые горизонтальные сверленые отверстия

2 - кольцо из плотного водонепроницаемого бетона

3 - засепка из гравия для фильтрации воды

4 - пласт земной пород

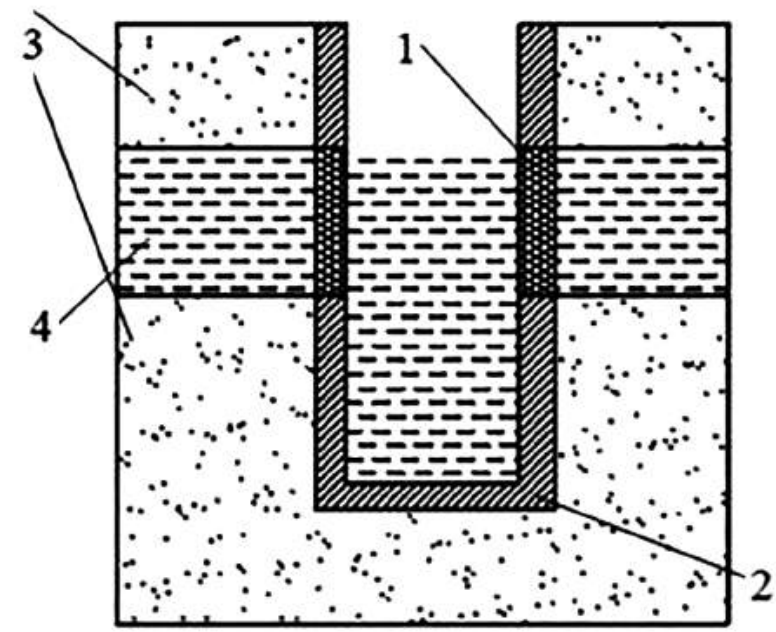

Рис. 3. Приток воды

через фильтры из крупнозернистого бетона

1 - кольцо из пористого бетона

2- кольцо из плотного водонепроницаемого бетона

3 - водонепроницаемая порода

4 - пласт земной породы

ные конструкции крепятся между собой скобами. Данный способ усложняет технологию возведения колодцев. Применение стеновых колец из бетона для колодцев обеспечивает долговечность, надежность, простота в устройстве, гигиеничность.

Армирование колец лучше не производить во избежание последующего разрушения колодца в результате коррозии арматуры.

Колодцы из бетонных колец для обеспечения безопасности от завалов земной породы монтируют опускным способом с постепенным их наращиванием. Равномерно подрывая грунт по периметру кольца, его опускают на всю высоту, затем сверху ставят следующее кольцо и подрывают грунт дальше. Чтобы проверить равномерность опускания кольца, берут 4 одинаковые опоры (кирпичи, деревянные чурки), выкапывают 4 углубления под кольцом, грунт между опорами удаляют и, кольцо, опускаясь, опирается только на них. Затем продолжают равномерно подкапывать грунт под противоположными опорами, пока кольцо полностью не опустятся. Постепенно углубляя шахту колодца, продолжают наращивать кольца до тех пор, пока нижнее бетонное кольцо не дойдет до необходимой отметки.

Нами проведены исследования по подбору состава крупнопористого бетона для фильтрованных колец. Пористый бетон приготовили из сульфатного портландцемента марки 500, при таком составе цемента уменьшается возможность образования в цементном камне гидросульфоалюмината кальция, тем самым повышая стойкость бетона к сульфатной коррозии. По сколько коррозия не будет разрушать бетон, фильтрация будет происходить постоянно. Применение обычного портландцемента не дает нужного эффекта из-за зарастания пор гидросульфоалюминатом кальция. В качестве заполнителя нами использовался щебень фракции 2,510 мм. В соотношении 1:5,1:6 и 1:7 при В/Ц=0,37. Подвижность бетонной смеси составило 2-3 см. Время вибрирование 5-10 с. Образцы изготавливали в виде цилиндров размерами $\mathrm{dH}=180 \mathrm{Mm}, \mathrm{dB}=100 \mathrm{Mм}$, высотою $\mathrm{h}=180 \mathrm{mм}$. Площадь внутренней поверхности образца составила 565,2см², объем образца 1,8 л. Результаты исследований приведены в таблице 1.

Таблица 1.

Подбор состава крупнопористого бетона для фильтрованных колец

\begin{tabular}{|c|c|c|c|c|}
\hline $\begin{array}{c}\text { № } \\
\text { п/п }\end{array}$ & $\begin{array}{l}\text { Состав бетона. } \\
\text { Соотношение } \\
\text { цемент:щебень }\end{array}$ & $\begin{array}{l}\text { Прочность } \\
\text { при сжатии, } \\
\text { кгс/см² }\end{array}$ & \begin{tabular}{|c} 
Прочность \\
при растя- \\
жении, \\
кгс/см
\end{tabular} & $\begin{array}{l}\text { Фильтрация } \\
\text { воды, л/с }\end{array}$ \\
\hline 1 & $1: 5$ & 150 & 46 & 1,6 \\
\hline 2 & 1:6 & 112 & 29 & 2,1 \\
\hline 3 & $1: 7$ & 86 & 18 & 2,5 \\
\hline
\end{tabular}

Из таблицы видно, что для заполнения кольца из бетона объемом 1 м $^{3}$ необходимо следующее время: площадь кольца равна $2 \pi \mathrm{Rh}=2.3,14.100=31400 \mathrm{~cm}^{2}$; тогда за 1 с кольца из крупнопористого бетона $\mathrm{dB}=100 \mathrm{~cm}$ наберет воду:

состав $1-31400 / 565: 1,6=88$ л, 1000/88=12 с;

состав $2-31400 / 565: 2,1=117 л, 100017=9$ с;

состав $3-31400 / 565: 2,5=139 л, 1000 /: 139=7,2$ с.

\section{Вывод}

Результаты проведенных исследований позволяют организовать работы по выпуску фильтрованных колец из крупнопористого бетона для колодцев с повышенной фильтрацией. Материалы для изготовления бетонных колец доступны, а работа не требует специальной квалификации.

Литература:

1. Биндеман Н. Н. Справочник по использованию подземных вод для полевого и временного водоснабжения, 1943.

2. Борисяк А. О горных обвалах в Крыму. Сб. памяти И. В. Мупшетова, 1905

3. Бутырин П. К вопросу изучения процессов карста. Мат. по гидрол., гидрогр., водным силам СССР, сер. 3, вып. 26,1935.

4. Гвоздецкий Н. А. Подземная топография. Природа, № 3, 1948.

5. Тугай А.М., Тугай Я.А. Водопостачання. Джерела та водозабірні споруди: Посібник. - Українсько-фінський інститут менеджементу і бізнесу. 1998. - 196 с.

6. Дзекунов Н.Е., Жернов И.Е., Файбышенко Б.А. Термодинамические мето-ды изучения водного режима зоны аэрации. - М.: Недра, 1987. - 176 с., ил.

7. Гаврилко В.М., Алексеев В.С. Фильтры буровых скважин. Изд. 2, перераб. и доп. М., «Недра», 1976. 345 с.

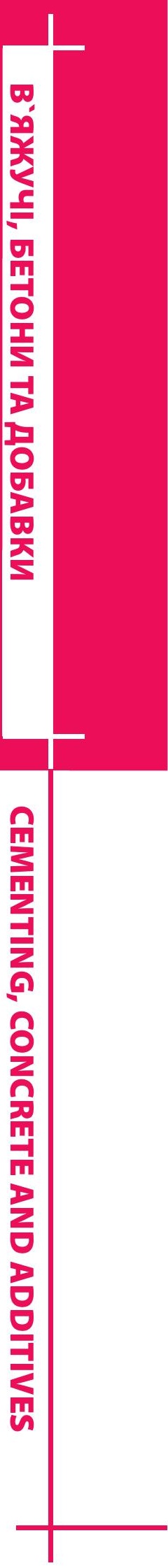

